CHAPTER 23

\title{
Humane Education: The Tool for Scientific Revolution in Brazil
}

\author{
Vanessa Carli Bones
}

Veterinarian, Veterinary Medicine Regional Council of the State of Paraná, Cascavel, Brazil

vcb.vete@gmail.com

Rita de Cássia Maria Garcia

Professor, Veterinary Medicine Department, Federal University of Paraná, Curitiba, Brazil

\section{Gutemberg Gomes Alves}

Professor, Institute of Biology, Fluminense Federal University, Niterói, Brazil; 1R Institute of Promotion and Research for the Replacement of Animal Experimentation, Poços de Caldas, Brazil

\section{Rita Leal Paixão}

Professor, 1 R Institute of Promotion and Research for the Replacement of Animal Experimentation, Poços de Caldas, Brazil; Institute of Biomedicine, Fluminense Federal University, Niterói, Brazil

\section{Alexandro Aluísio Rocha}

Professor, Animal Science Department, Faculty of Agrarian Sciences, Federal University of Vales do Jequitinhonha e Mucuri, Brazil

\section{Karynn Capilé}

PhD Student, Post Graduate Program in Bioethics, Applied Ethics and Public Health, Fluminense Federal University, Niterói, Brazil

\section{Róber Bachinski}

Researcher and Director of the 1 R Institute, 1 R Institute of Promotion and Research for the Replacement of Animal Experimentation, Poços de Caldas, Brazil. 
Despite the predominance of traditional teacher-centered approaches, educators are constantly changing paradigms and social boundaries, by stimulating criticism with active learning based approaches, which are centered on contexts and experiences. Viewing students as individuals enables paradigm changes and inspires new perspectives on established theories and facts. This chapter discusses education in Brazil, with a focus on humane education. Humane education strives to foster compassion and respect for humans, nonhuman animals (hereinafter referred to as animals), and the environment by creating awareness of the needs of others and the effects of our actions. In this chapter we describe the process of humane education in the context of animals used for teaching. We explore the possibilities of replacing animals and including ethical discussions in the curriculum; the history of Brazilian humane education, considering the Environmental Crimes Act that forbids animal use when alternative methods exist; and the legislation that controls the use of animals for research and teaching purposes in Brazil.

\section{$2 \quad$ Moving towards Humane Education}

In the context of animals used for experimentation, education, and training purposes, humane education is a process that leads to a more egalitarian, critical, and fair society that has ethical consideration towards animals (Faver, 2010). To achieve this, we have to consider approaches that include an educational and moral revolution. However, for such a revolution to happen effectively, two common reasons for the justification of animal use need to be considered. First, maintenance of the current paradigm, whereby both academic staff and students use and harm animals. Second, the social speciesism that exists in regarding animals as instruments or tools for science. In terms of maintenance of the current animal experimentation paradigm, harmful animal use puts students in a kill-to-save dilemma, encouraging thinking that animal use in practical classes is necessary. This conflict can result in the exclusion of students who are ideologically oriented against animal experimentation, ultimately leading to their exclusion as potential researchers who could work towards animal replacement methods. Even in situations where academic staff are not comfortable with using animals, the maintenance of this system represents a negative feedback loop for the advancement of scientists favoring animal research. Speciesism is also rife within the current paradigm, 
for example, many scientists avoid using some animal species, such as dogs, for training surgery and favor the use of pigs. This situation is common in some veterinary and medical courses in Brazil. The choice for species to be "protected" from experimentation can also originate from social pressure (e.g., the use of animals regarded as "pets") as well as from ethical restraints. In this situation, the choice of species does not consider nervous system development, the existence of a conscience, or the experience of pain and suffering.

From an anti-speciesist standpoint, animal objectification is a recognized feature of human-animal relations that should be tackled as an unjust social tendency in all areas where it occurs. Education courses that involve animal handling may result in students' desensitization toward animals' pain and suffering, as a mechanism to resolve the cognitive dissonance generated by the unpleasant experience of witnessing animal discomfort (Amiot and Bastian, 2015; Woon, 2011; Zanetti, 2010). Thus, students are often led to deny the subjectivity of animals, as well as their cognitive and emotional capacities, regarding them as "things".

Many students feel uncomfortable when engaging in practices that may cause an animal pain or discomfort however, they are not encouraged to express their concerns (Capilé et al., 2015). In this situation, students should be informed about their right to object, and how they can exercise this right; this is a significant pursuit of humane education (Knight, 2014). Recognizing students' objections to participating in harmful animal use is essential to the goal of replacing animals in education and training (Seixas et al., 2010). In Brazil, there is a legal provision, whereby one is allowed to be exempt from participating in such acts that offend one's moral positions or beliefs by expressing consciousness objection (República Federativa do Brasil, 1988). Practicing humane education of students right to withdraw enables protection mechanisms for students to avoid classes that cause mental conflict, encouraging an academic mind shift based on morals and ethics. Furthermore, on a long-term basis, this could nurture students' interaction with animals more as individuals, enabling these future professionals to participate in building a more ethical mindset in the way humans treat other animals.

Animal Replacement for a Humane Science

In analyzing the moral limits of science in human experimentation, Edgar Morin (1990) described the ethics of this science as based on social control and scientists' awareness of moral barriers. Thus, although biotechnology is 
constantly advancing new ways for carrying out research and testing without animals, it is moral barriers and empathic education that can protect animals from the harms of "scientific exploration". Without a critical animal ethics curriculum for science in schools and higher education, the mindset of the current paradigm of animal use is maintained.

By observing instances where humans have been the subject of experimentation in the past century, we can identify (in addition to political, legal, and regulatory changes) a positive ethical paradigm change based on humane education. Ethical concerns over the use of human experimentation are frequently traced back to the Nuremberg Trials, which resulted in the Nuremberg Code, making informed consent in human experimentation compulsory (Nuremberg Military Tribunals, 1946). However, the existence of this guideline can be traced back as early as the nineteenth century. The Prussian Regulation, published by the Minister for Religious, Educational, and Medical Affairs in 1900, was based on the principle of personal autonomy and presented an early model of informed medical consent (Annas and Grodin, 1992). By 1931, during the political reform of criminal law in Germany, the Dritte Reich government issued the Guidelines for New Therapy and Human Experimentation, differentiating between therapeutic and non-therapeutic human experimentation. These regulations were based on patient autonomy and reinforced the doctrine of informed consent (Jochen-Vollmann, 1995; Vollmann and Winau, 1996; Reich Minister of the Interior, 1931). Unfortunately, these legal parameters were not enough to protect vulnerable humans during the Nazi period, as described in the Nuremberg Trials (Nuremberg Military Tribunals, 1946); nor did they prevent other unethical human experimentation across the Western world (Comisióntécnica, 2011; Frieden and Collins, 2010; Horner, 1999; Seidelman, 2012). These historical accounts bring to mind the power relations involved in human and animal experimentation, where sentient beings are transformed into scientific instruments (Comisión-técnica, 2011; Horner, 1999; Teixeira, 2011; Torrey and Yolken, 2010). After the establishment of Nuremberg Code, obtaining data from animal tests became compulsory to protect human volunteers and patients in clinical trials. However, the placement of animal models as simply a protection mechanism for humans, and not because they are an advanced scientific model, demonstrates that the animal experimentation paradigm exists primarily because animals act as a moral barrier to prevent human experimentation.

The criticism around human experimentation, and the public dissemination of examples where humans have been experimented on, ensures consideration of ethical concerns before starting any type of scientific project involving humans. In this case, moral progress is the only factor capable of stopping unethical research. The same should apply to animal experiments. To work towards 
a much-needed change of paradigm away from using animals for research, education, and training, we need to start by recognizing that animals are not mere objects for research, but their own individual agents. A humane education system has the potential to deconstruct the speciesism present in current scientific education and training, helping us to consider the basic rights of animals.

At the beginning of the 1990s, the use of animals at Brazilian universities was the norm, particularly for biomedical teaching, continuing the paradigm in which learning is entirely dependent on animal use. Students were coerced into participating in classes using animals and were reluctant to discuss the matter and express their opinions. An investigation carried out at the beginning of the 1990s in Brazil, with students across different education levels, revealed that vivisection was an unpleasant practice for the majority; $68 \%$ of university students referred to it as a "necessary evil" and $72.4 \%$ explicitly talked about their dislike of the method (Lima, 1995).

The debate about animal use for education and training in Brazil started in the late 1990s and has grown ever since. An important landmark was the Brazilian Environmental Crimes Act, Law 9605 of February 12, 1998 (República Federativa do Brasil, 1998). According to this law, a crime can be considered commissive, when somebody uses an animal in a way that causes them intentional pain and suffering; or omissive, when somebody acts in a neglectful manner towards an animal. Both crimes can be applied to animals that are used for experimentation and education. In the case of omissive crimes, the law considers causing animals painful or cruel experiences a crime, even for educational or scientific purposes, when non-animal alternatives are available. With this law, two important shifts occurred: 1. a previously invisible social movement became visible to the media and government in Brazil; and 2. the need to replace the use of animals in education and training became evident.

In 2002, a few years after the publication of the Environmental Crimes Act, a study was conducted to investigate the use of animals and their alternatives in medical education, as well as teachers' attitudes towards the use of animals for teaching purposes (Bastos et al., 2002). Seven medical schools in the cities of Rio de Janeiro and Niterói were selected to survey teachers who used animals in their courses. The results revealed that four in seven institutions used animals in various courses. Most of the participants were unaware of laws relating to animal use and did not believe in discontinuing these practices. The 
study indicated that there was need to raise greater awareness of innovative educational methods and increase discussions about animal ethics in medical education. As a result of increasing awareness of the ethics surrounding animal use and the replacements available, bioethics courses were introduced in Brazil by the end of the 1990s. With the inclusion of bioethics subjects in biological and biomedical courses, the debate on animal use could begin. However, despite these early efforts, a recent study investigating the curricular integration of bioethics and similar learning opportunities in undergraduate biology programs at Brazilian federal institutions found that of 36 programs, only $19(53 \%)$ included bioethics or similar courses for biology degrees (Dória and Moreira, 2011). Furthermore, increased emphasis on bioethics is strongly linked to medical practice, for example, the choice of subjects of study and the academic and professional trajectory of researchers (Diniz and Guilherm, 2002). It is clear that a more holistic approach is needed, one that covers human, animal, and environmental issues in bioethics. Moreover, we need to expand the public discussion of bioethics and include students of veterinary medicine and pharmacy, as well as biology, among others.

Regarding the regulation of animals used in research, education, and training in Brazil, it is noteworthy that the Animal Use Ethics Committees (AUECs), Comissões de Ética no Uso de Animais in Portuguese, were only officially established in 2008 (República Federativa do Brasil, 2008). Although AUEcs exist in several institutions in Brazil, and their numbers are increasing, several conflicts have occured in these committees. For example, if a teacher justifies the use of animals as relevant for learning in their course and tells the AUEC that they cannot be replaced, the course will be authorized. However, it is difficult for AUECs members to know if a certain practice is, in fact, performed according to their approval because the actual activities are not monitored. Therefore, once a project is approved by an AUEC, the teaching staff can act as they wish; and proponents of animal use often do not follow AUEC recommendations for the replacement of animals in their teaching. Adding to this issue, there is still no way to gather information about and assess, officially, the situation of animal use in Brazil. Information on numbers, species, procedures, and degree of invasiveness is not publicly available, although a database for this kind of information may be under construction (Bachinski et al., 2015). of the Brazilian Environmental Crimes Act

After the publication of the Brazilian Environmental Crimes Act (República Federativa do Brasil, 1998), several Brazilian institutions and university 
departments took a stand against the harmful use of animals in teaching and training, fully replacing this practice in some courses. As such, it is worthwhile to mention some examples:

- In 1990, Federal Fluminense University (UFF) replaced harmful animal use in the physiology classes of the biomedical program with the use of cell cultures; and since then, they have been teaching the relevance of in vitro assays as alternatives to animal use (Silva et al., 2012). In 2012, the UFF, together with the Brazilian National Network on Alternative Methods, hosted the Latin American Congress on Alternative Methods, a biannual event that gathers researchers from around the world to discuss developments in alternatives to animal use in science, industry, and education.

- The Federal Rural University of Pernambuco, in the State of Pernambuco, abolished the use of live animals for surgical training, as part of their veterinary medicine training, over 16 years ago. They now use preserved ethically-sourced cadavers, synthetic models, and in-house created simulators and are developing many other materials (Souza, 2014). [The term ethically sourced cadaver refers to cadavers and tissue obtained from animals who died of natural causes or in accidents, or were euthanized because of a terminal disease or non-recoverable injury; and, from humans who, prior to their death, gave persmission for their body and tissue to be used (Martinsen and Jukes, 2007)].

- The University of Brasilia, in Distrito Federal, replaced the harmful use of animals with computer simulations in practical classes in 1998. Their microsurgical techniques training was replaced by simulators that use a PVC mouse attached to a computer simulator as a teaching interface (Souza, 2014).

- The team at the Faculty of Veterinary Medicine and Animal Science at University of São Paulo achieved an important milestone for more humane education by gaining international recognition for developing a preservation technique that employs a modified Larssen solution (da Silva, 2003; da Silva et al., 2004). This solution is based on a higher concentration of glycerin and lower concentration of formaldehyde and allows the preservation of ethically-sourced cadavers for up to one year and their thawing between six and 10 times without the loss of organoleptic characteristics. The reduced concentration of formaldehyde makes the modified Larssen solution less toxic, which benefits students, technicians, and teachers. The preserved material retains adequate color and texture, ideal for practical classes in anatomy, surgical techniques, and other disciplines, such as orthopedics. More recently, the research group published a refinement of the first developed model, which consists of adding artificial blood to the system to simulate situations, such as bleeding and the use of hemostatic techniques (de Souza and Matera, 2015). 
- In 2007, the Federal University of Pelotas completely banned the harmful use of live animals in all courses.

- Since 2006, the Higher Education Center of Campos Gerais at Paraná State has involved veterinary medicine students in helping develop non-animal models as part of their physiology classes to increase their knowledge and problem-solving skills. In 2015, 27 low-cost models were presented by students to their classmates, including models of renal circulation, respiratory homeostasis, the digestive system of ruminants and non-ruminants, ovulation, spermatogenesis, and synapses (Bachinski et al., 2015; Ruiz, 2014).

- In 2007, the Faculty of Medicine of the Federal University of Rio Grande do Sul implemented the Laboratory Practice of Surgical Techniques and promoted the full replacement of harmful animal use for medical training.

- Still in 2007, and as a result of an internal initiative, the Faculty of Medicine at the ABC Foundation, in the State of São Paulo, prohibited the harmful use of live animals. The animals used in practical classes of physiology and pharmacology were replaced by interactive software and ethically-sourced animal cadavers.

- The Catholic University of Pelotas, in the State of Rio Grande do Sul, replaced harmful animal use in practical classes of physiology and pharmacology in 2008.

- At the Regional University of Northwest of the State of Rio Grande do Sul (UNIJUí) initiatives to replace animals in education started with the opening of the veterinary medicine program in 2008. For example, in the veterinary surgical course, students practice suturing on foam tissue models or other available non-animal materials. Students then perform surgeries on live animal patients who need certain procedures or who are to be neutered or spayed. The same process has been utilized by other Brazilian universities. Since 2016, the UNIJUÍ also started using other alternative methods, such as artificial bones that simulate fractures and their reconstruction, as well as chemically preserved cadavers using Thiel solution (Thiel, 1992). As part of veterinary anesthesiology classes, students have the opportunity to learn how to restrain an animal and provide drugs using dog mannequins. Furthermore, in 2016, students developed models of different body systems in their physiology class.

- In 2009, the veterinary medicine degree at the University Center Monte Serrat (Unimonte) abolished the harmful use of animals and received the Brás Cubas Merit Medal in April of that year for this move.

- In 2013, the Federal University of Vales do Jequitinhonha e Mucuri at Minas Gerais State provided students the opportunity to develop alternative 
methods to animal use in their animal anatomy and physiology classes for agricultural science degrees. The animal anatomy course now allows students to develop anatomical pieces based on ethically-sourced animal cadavers. Animal replacements for students studying animal physiology include, physiological models with molecular and macroscopic levels, such as dynamic models of myosin-actin protein molecule interactions, and models that demonstrate circulation. There are also models that display biophysical components, such as surface tension and pressure variations in vascular beds.

- In the past six years, students and researchers have developed models for veterinary training at the Federal University of Paraná at Paraná State. Alternative methods include, mannequins as a scaffold for training models of different systems, such as cystocentesis, blood collection in dogs and cats, and prostatic palpation.

- More recently, in 2015, a project aiming to develop and implement humane teaching techniques for veterinary and biology courses was carried out at the Rural Federal University of Rio de Janeiro, in Rio de Janeiro State. This project includes the use of ethically sourced cadavers, developing models, as well as interacting with local state schools for the dissemination of humane research methods and scientific communication.

Policy Development Related to Animals Used in Research and Teaching in Brazil and Its Relevance to Humane Education

In addition to the Environmental Crimes Act, Brazil regulates animal production and use for research and education purposes by Federal Act 11894/2008, protecting vertebrate animals (República Federativa do Brasil, 2008). This Act restricts animal breeding and use for higher education and professional training in biomedical sciences. The Act also created the National Council for the Control of Animal Experimentation (CONCEA), which is a government organization related to the Ministry of Science, Technology, Innovations, and Communications. Invertebrate animals, however, were not included in this Act, which is a critical omission in the protection of animals in Brazil, in comparison to other nations where certain classifications of non-vertebrates, such as cephalopods, are protected (European Parliament, 2010, Article 1).

According to Federal Act 11894/2008 (República Federativa do Brasil, 2008), CONCEA formulates standards for animal use in research and teaching, monitors and evaluates the introduction of alternative techniques that replace their 
use, and maintains an updated register of research and teaching procedures and of researchers involved in animal use, among other responsibilities. All institutions with teaching or research activities using animals are obliged to set up AUECs, which are composed of veterinarians and biologists, professors and researchers in specific scientific fields, and a representative of a Brazilian animal protection society. All animal teaching and research procedures must be approved by AUECs and reported to CONCEA. From an organizational standpoint, CONCEA has permanent structures to deliberate about animals used in research, education and training, breeding, and development and use of alternative methods, as well as providing parliamentary and media assistance. The decisions of all chambers are voted on in a plenary meeting of the council, consisting of 14 delegates and their alternate members, totaling 28 councilors: 12 from federal public agencies, 12 from civil non-profit organizations linked mainly to research, and only 4 non-profit civil associations for animal protection. Considering the institutional interests, in general terms, the majority (24 individuals) are interested in the "ethical use of animals" and only 4 individuals, from animal protection groups, aim to recognize and protect animals' interests.

All CONCEA delegates are appointed by their institutions, but animal protection delegates are not elected by direct designation. Delegates from animal protection groups are subjected to an evaluation by an ad hoc committee, composed of three CONCEA external members. The final decision regarding the council's composition is made by the Minister of Science, Technology, Innovation, and Communication. Unfortunately, the process of selection may allow the election of delegates with no history of interest in animal protection. For example, a researcher from a Primatology Center has been a representative of animal protection groups at CONCEA, implicating a possible conflict of interest. Nevertheless, animal protection delegates do have the opportunity to be part of the discussions and decisions regarding the use of animals in research and education, although their delegates rarely participate in AUECs. This lack of local representation often comes from a lack of knowledge of the CONCEA legislation and background suited to the ethical and technical discussions. Nonetheless, this should not be considered a barrier to the inclusion of animal protection representatives in AUECs, as many come from scientific and technology backgrounds.

In 2016, CONCEA's teaching chamber organized the first Symposium on Alternative Methods for the Use of Animals in Education, generating a space for discussion and exchange of knowledge on alternative methods used for teaching in Brazil. The event welcomed students, professors, and third 
sector organizations. The teaching chamber is also involved in the proposition of regulations for the evaluation of the welfare of animals; promotion of humane education in scientific activities; the establishment of values, principles, and guidelines for animals used in research and education; and support for the development and use of alternative methods in surgical training. It is of utmost importance that the AUECs, in line with CONCEA's actions, are kept informed about all available alternative methods and new learning approaches. With this information, projects proposing the use of animals for education and training can be evaluated according to their merits and whether animal replacement methods are available. Often, harmful animal use is proposed by teachers who have repeated a "tried-and-tested" practice for decades without searching for more technologically advanced methods that do not used live animals; and they do not seek to base their classes on humane, ethical values. To increase consideration and implementation of the ${ }_{3}$ Rs (replacement, reduction, and refinement) (Russell and Burch, 1959), the AUECs should require that project applications provide a detailed scientific literature review, including search strategy, list of databases used, keywords, and scientific citations (Shapiro, 1999).

Final Considerations and Perspectives

Souza (2014) described the evolution of moral and social thinking about the status of animals in Brazil, especially addressing their use as a scientific and training instrument. Following a detailed analysis of literature on humane education and animal use in education and of academics' and students' opinions, Souza concluded that the use of animals in teaching could not be accepted for ethical, legal, and pedagogical reasons. There are economic reasons to avoid their use as well. Research shows that the use animals for research, education, and training costs more than the use of alternative methods (Bones et al., 2015; Feijó et al., 2008; Fox et al., 2013; Neto, 2011; Ribeiro et al., 2013; Sathyanarayana, 2009; Tudury et al., 2009).

Despite awareness that animals should not be used for education and training purposes, their use continues in some institutions in Brazil. With this consideration, it is important to analyze the main reasons for retaining their use. For example, in a study focusing on animal use for rabies diagnosis, the proportion of tests that used mice was higher in Brazil $(75 \%)$ than in other countries $(32 \%)$. Moreover, barriers to the replacement of animal use most frequently cited by respondents in a 2014 study by Bones and colleages 
included: lack of structure, equipment, and materials in the laboratories; lack of financial resources; lack of human resources and professional qualifications; resistance to change; regulatory obstacles, and lack of incentive by the government (Bones et al., 2014). Although this study refers to the use of animals for testing purposes, its findings on barriers to for implementing non-animal methods are indicative to other areas of animal use, including education and training.

Within teaching, resistance to change is one of the most difficult problems at universities in Brazil. Barriers to the replacement of animal procedures could be addressed by focusing on humane education, using a novel tool: a decision tree (DT) approach (Bones et al., 2016). The DT approach discusses barriers that hinder replacement and helps to address the main obstacles. If followed in a step-by-step manner, the DT approach can lead to the uptake of alternative methods or their development when alternatives do not already exist. For example, for the resistance barrier, the DT approach suggests the need to obtain financial resources, to develop courses on the ${ }_{3} R s$ and courses on the ethics of animal use, and to provide people with information about the Environmental Crimes Act (República Federativa do Brasil, 1998). The DT approach can be applied to laboratory animal use scenarios, where alternative methods already exist, and could contribute to increased compliance with the legal requirement of the 3 Rs principles in Brazil.

In addition to the application of DT methods, we suggest other actions to accelerate the process of preventing harmful use of animals in education and training. For example, strengthening student movements that value ending the harmful use of animals; pressuring the government to increase funding for the development of alternative methods; and implementing more humane education discussions. Alongside these actions, both teachers and students need to monitor the availability of alternative methods and legal mechanisms for greater protection of animals used in education. Approaches that involve students in the development of animal-free methods should be a vital part of academic and vocational training (Bachinski et al., 2015).

As a final note, the work of the Brazilian Network for Humane Education (RedEH) needs to be acknowledged. Starting in 2015, this network provides a platform to connect researchers and teachers from various science and educational institutions across the country to engage in promoting scientific education on the replacement of animals used in education and training activities (RedEH: Bachinski et al., 2015). RedEH's main objective is the development and dissemination of new teaching methods and public policies in Brazil and sharing teaching experiences without the involvement of animal harm. RedEH also constitutes a link between teachers and researchers, providing 
opportunities for collaboration using new techniques and methods developed by the members. As a result of these actions, several institutions have already stopped harmful animal use in favor of humane approaches. RedEH is gradually expanding its actions in Brazil, each year counting the collaboration of an increasing number of educators. Initiatives involving teacher and student collaboration and including more active engagement can enable a humane scientific paradigm shift among educators and students. As well as working for the replacement of harmful animal use and increasing the ethical regard for animals as individuals, and not as tools, RedEH also works on issues of social equality and justice.

In this chapter we have discussed actions based on social participation in scientific-political decisions. Considering science as a social production, with social limits and social demands, we encourage ideological pluralism in scientific development and looking for new opportunities for a non-speciesist scientific paradigm. Humane education, social participation, and defense for new scientific perspectives that respect basic animal rights are important for any society interested in the development of humane science.

\section{References}

Amiot, C.E. and B. Bastian (2015). Toward a Psychology of Human-animal Relations. Psychological Bulletin, 141(1), pp. 6-47.

Annas, G.J. and M.A. Grodin (1992). The Nazi Doctors and the Nuremberg Code. New York NY: Oxford U Press.

Bachinski, R., T. Tréz, G.G. Alves, R. de CM Garcia, S.T. Oliveira, L.D.S. Alonso, J.X. Heck, C.M.C. Dias, J.M. Costa Neto, A.A. Rocha, V.R.R. Ruiz and R.L. Paixão (2015). Humane Education in Brazil: Organisation, Challenges and Opportunities. Alternatives to Laboratory Animals, 43(5), pp. 337-344.

Bastos, J.C.F., A.M. Rangel, R.L. Paixão and S. Rego (2002). Implicações Éticas do Uso de Animais no Processo de Ensino-aprendizagem nas Faculdades de Medicina do Rio de Janeiro e Niterói. Revista Brasileira de Educação Médica, 26(3), pp. $162-170$.

Bones, V.C., H.C. Clemente, D.M. Weary and C.F.M. Molento (2014). Perceived Barriers to the Adoption of Alternatives to Laboratory Animal Use for Rabies Diagnosis. Alternatives to Laboratory Animals, 42(3), pp. 171-179.

Bones, V.C., C. Forte and M. Molento (2016). The Use of a Decision Tree Based on the Rabies Diagnosis Scenario to Assist the Implementation of Alternatives to Laboratory Animals. Alternatives to Laboratory Animals, 44(8), pp. 121-128.

Bones, V.C., A.H. Gameiro, J.G. Castilho and C.F.M. Molento (2015). Comparative Costs of the Mouse Inoculation Test (MIT) and Virus Isolation in Cell Culture (VICC) 
for Use in Rabies Diagnosis in Brazil. Alternatives to Laboratory Animals, 43(2), pp. $81-87$.

Capilé, K.V., G.M.B. Campos, R. Stedile and S.T. Oliveira (2015). Canine Prostate Palpation Simulator as a Teaching Tool in Veterinary Education. Journal Of Veterinary Medical Education, 42(2), pp. 146-150.

Comisión-técnica (2011). Experimentos en Seres Humanos el caso Guatemala 1946-1948. Guatemala. [online] Available at: http://www.cityprojectca.org/blog/wp-content/ uploads/2012/07/Guatemala-Report-Consentir-Spanish-201110.pdf [Accessed 26 August 2017].

da Silva, R.M.G. (2003). Avaliação do Método de Ensino da Técnica Cirúrgica Utilizando Cadáveres Quimicamente Preservados, Dissertação (mestrado) - Universidade de São Paulo. Faculdade de Medicina Veterinária e Zootecnia. Departamento de Cirurgia. [online] Available at: http://revistas.bvs-vet.org.br/recmvz/article/view/3263 [Accessed 26 August 2017].

da Silva, R.M.G., J.M. Matera and A.A.C.M. Ribeiro (2004). Preservation of Cadavers for Surgical Technique Training. Veterinary Surgery, 33(6), pp. 6o6-6o8.

de Souza, I.M.C.C.M. and J.M. Matera (2015). Bleeding Simulation in Embalmed Cadavers: Bridging the Gap Between Simulation and Live Surgery. Alternatives to Animal Experimentation, 32(1), pp. 59-63.

Diniz, D. and D. Guilhem (2002). O que é bioética. Coleção Pr. São Paulo, Brazil: Brasiliense.

Dória, T.A.F. and L.M de A. Moreira (2011). A Bioética na Formação do Biólogo: Um Desafio Contemporâneo. Revista Faced, 20, pp. 99-122.

European Parliament (2010). Directive 2010/63/EU of the European Parliament and of the Council of 22 September 2010 on the protection of animals used for scientific purposes. Official Journal of the European Communities, L276, pp. 33-79. [online] Available at: http://eur-lex.europa.eu/legal-content/EN/ TXT/?uri=CELEX\%3A32010Loo63 [Accessed 26 August 2017].

Faver, C.A. (2010). School-based Humane Education as a Strategy to Prevent Violence: Review and Recommendations. Children and Youth Services Review, 32(3), pp. 365-370.

Feijó, A., A. Sanders, A.D. Centurião, G.S. Rodrigues and C.H.A. Schwanke (2008). Análise de Indicadores Éticos do Uso de Animais na Investigação Científica e no Ensino em uma Amostra Universitária da Área da Saúde e das Ciências Biológicas. Scientia Medica, 18(1), pp. 10-19.

Fox, V., C. Sinclair, D.M. Bolt, J. Lowe and R. Weller (2013). Design and Validation of a Simulator for Equine Joint Injections. Journal of Veterinary Medical Education, 40(2), pp. 152-157.

Frieden, T.R. and F.S. Collins (2010). Intentional Infection of Vulnerable Populations in 1946-1948: Another Tragic History Lesson. Journal of the American Medical Association, 304(18), pp. 2063-2064. 
Horner, J.S. (1999). Retreat from Nuremberg: Can We Prevent Unethical Medical Research?. Public Health, 113(5), pp. 205-210.

Jochen-Vollmann, R.W. (1995). History of Informed Medical Consent. The Lancet, 346(8990), p. 1633 .

Knight, A. (2014). Conscientious Objection to Harmful Animal Use within Veterinary and Other Biomedical Education. Animals, 4, pp. 16-34.

Lima, J.E.R. (1995). Vozes do Silêncio. Cultura científica: ideologia e alienação no discurso sobre vivissecção. São Paulo, Brazil: Instituto Nina Rosa.

Martinsen, S. and N. Jukes (2007). Ethically Sourced Animal Cadavers and Tissue: Considerations for Education and Training. Alternatives to Animal Testing and Experimentation, 14, Special Issue, Proceedings of the 6th World Congress on Alternatives and Animal Use in the Life Sciences, pp. 265-268. [online] http://altweb.jhsph.edu/wc6/paper265.pdf Available at: [Accessed $26 \mathrm{Au}-$ gust 2017].

Morin, E. (1990). Science avec conscience. Librairie Artheme Fayard, 1982; Paris: Seuil. [online] https://monoskop.org/images/e/e5/Morin_Edgar_Science_avec _conscience.pdf Available at: [Accessed 26 August 2017].

Neto, F.C. (2011). Desenvolvimento e análise de software educacional alternativo ao uso de animais em aulas práticas de fisiologia: Fisioprat. Campinas: Universidade Estadual de Campinas.

Nuremberg Military Tribunals (1946). Trials of war criminals before the Nuremberg Military Tribunals under Control Council Law no. 10. Washington D.C.: U.s. Government Printing Office.

Reich Minister of the Interior (1931). German Guidelines on Human Experimentation 1931. In: Reich, W.T., ed., Encyclopedia of Bioethics (1978), Appendix p. $2762-2763$.

República Federativa do Brasil (1988). Constituição Da República Federativa Do Brasil. Promulgada em 5 de outubro de 1988. [online] Available at: http://www.planalto.gov.br/ccivil_03/constituicao/constituicao.htm [Accessed 26 August 2017].

República Federativa do Brasil (1998). Lei No 9.605, De 12 De Fevereiro De 1998. Diário Oficial da União. Seção 1 - 13/2/1998, Página 1.

República Federativa do Brasil (2008). Lei No 11.794, de 8 de Outubro de 2008. Diário Oficial da União. Seção 1 - 9/10/2008, Página 1.

Ribeiro, C.L., C.R. Bittencourt, C.A.C. Ponczek, I.R.B. Filho and S.T. Oliveira (2013). Confecção de Modelos Artificiais de Baixo Custo Como Auxílio Aprendizagem de Acesso Vascular em Pequenos Animais. Archives of Veterinary Science, 18(4), pp. $25^{-30}$.

Ruiz, V.R.R. (2014). Preparation of Alternative Teaching Materials to be Applied in the Relation of Teaching: Learning in Veterinary Medicine, Vigilância Sanitária em Debate, 2(3), pp. 22. 
Russell, W. and R. Burch (1959). The principles of humane experimental technique. Potters Bar, Hertfordshire, England: Universities Federation for Animal Welfare. [online] Availabe at: http://altweb.jhsph.edu/pubs/books/humane_exp/het-toc [Accessed 15 August 2017].

Sathyanarayana, M.C. (2009). Need for Alternatives for Animals in Education and the Alternative Resources. Alternatives to Animal Experimentation Proceedings, Proceedings of Animal Alternatives in Teaching, Toxicity Testing, and Medicine, 2(1), pp. 77-81.

Seidelman, W.E. (2012). Dissecting the History of Anatomy in the Third Reich (19892010): A Personal Account. Annals of Anatomy - Anatomischer Anzeiger, 194(3), pp. 228-236.

Seixas, M.M., J.H.A. Virgens, S.M.M. Barrouin and A.G.S. van Herk (2010). Consciência na Substituição do Uso de Animais No Ensino: Aspectos Históricos, Éticos e de Legislação. Revista Brasileira de Direito Animal, 6(5), pp. 71-96.

Shapiro, L.S. (1999). Applied Animal Ethics. D.T. Learning, Albany: Ari Farms.

Silva, D.C., J.A. Cortes, R. Bachinski and G. Alves (2012). An Integrated Practical Course on Cell Biology on in Vitro Cytotoxicity Assays for Brazilian Health/Biology Undergraduate Students. Alternatives to Animal Experimentation Proceedings, 3, p. 154.

Souza, M.F. (2014). Status Moral dos Animais: Percepções e Ações Sociais no Brasil. PhD. Programa de Pós-Graduação em Bioética, Ética Aplicada e Saúde Coletiva - PPGBIOS, em associação UFRJ, FIOCRUZ, UERJ E UFF.

Teixeira, M. (2011). Os Experimentos da Guatemala: Infecção Intencional de Presos, Soldados e Insanos pela Laboratório de Pesquisa em Doença Venérea dos EUA, Rev. Revista Latinoamericana de Psicopatologia Fundamental, 14(4), pp. 69o-698.

Thiel, W. (1992). Die Konservierung Ganzer Leichen in Natürlichen Farben. Annals of Anatomy-Anatomischer Anzeiger, 174(3), pp. 185-195.

Torrey, E.F. and R.H. Yolken (2010). Psychiatric Genocide: Nazi Attempts to Eradicate Schizophrenia. Schizophrenia Bulletin, 36(1), pp. 26-32.

Tudury, E.A., M.G Potier and T.H.T. Fernandes (2009). Métodos Alternativos para Aprendizado Prático da Disciplina Técnica Cirúrgica Veterinária. Ciência Veterinária nos Trópicos, 11(1), pp. 92-95.

Vollmann, J. and R. Winau (1996). Informed Consent in Human Experimentation before the Nuremberg Code. British Medical Journal, 313(7070), pp. 1445-1449.

Woon, S.Y. (2011). A Veterinary Student's Perspective on Educational Animal Use and the Potential for Humane Alternatives. Alternatives to Animal Experimentation Proceedings, 1(12), Proceedings of WC8, pp. 377-385.

Zanetti, M.B.F. (2010). Os animais como recurso didático nas aulas de medicina veterinária: Estudo em universidades do estado do paraná. Federal University of Paraná. 